\title{
Violation of Good Corporate Governance (GCG) Principles in the Delivery of 2018 Financial Statements
}

\author{
Martin Batara Tambunan ${ }^{1 *}$, Budiharto ${ }^{2}$, Sartika Nanda Lestari $^{3}$ \\ \{bataramartin@gmail.com ${ }^{1 *}$, budiharto ${ }^{2}$, sartikananda@live.undip.ac.id ${ }^{3}$ \} \\ Fakultas Hukum, Universitas Diponegoro, Jl. Prof. H. Soedarto, S.H., Semarang, Indonesia 50275 1,2, 3
}

\begin{abstract}
The application of the principle of Good Corporate Governance (GCG) is one of the important steps to increase and maximize company value, and encourage professional, transparent and efficient company management in order to continue to exist in global competition. However, along with its development, demands for GCG implementation for public companies namely the Capital Market sector is very important. The application of GCG principles in the Capital Market sector is closely related to the principle of disclosure. So, by applying the principles of GCG, it is expected to have a significant positive effect on the quality of financial statements submitted by the company. However, in the practice of PT Garuda Indonesia, there were violations in submitting its 2018 financial statements which led to the imposition of administrative sanctions by the Financial Services Authority, the Indonesia Stock Exchange and the Ministry of Finance.
\end{abstract}

Keywords: GCG Principles, Capital Markets, Disclosure Principles, Financial Statements.

\section{Introduction}

The implementation of Good Corporate Governance (GCG) is one of the important steps to increase and maximize company value, and encourage professional, transparent and efficient company management in order to continue to exist in global competition.[1] The legal basis for banks in implementing GCG for companies in Indonesia is Law Number 40 of 2007 concerning Limited Liability Companies (UUPT),[2] refers to Bank Indonesia Regulation No.8/4PBI/2006 concerning GCG Implementation for Commercial Banks and for State-Owned Enterprises (BUMN),[3] refers to SOE Ministerial Regulation No. PER01/MBU/2011 concerning the Implementation of Good Corporate Governance (GCG) in SOEs, [4] which was later refined in SOE Ministerial Regulation No. PER-09/MBU/2012. [5]

Normatively, GCG is the principles that underlie a company management process and mechanism based on laws and regulations and business ethics. As for the principles of GCG itself, namely transparency, accountability, responsibility, independence and fairness and equality are needed to achieve sustainability. business (sustainability) company with stakeholders (stakeholders).[6]

The application of GCG principles, along with its development is one of the pillars of the market economy. The demand for GCG implementation for public companies, namely in the Capital Market sector, is very important. The application of GCG principles in the Capital Market sector is closely related to the principle of disclosure as stipulated in Law Number 8 of 
1995 concerning Capital Market (UUPM) which aims to protect the interests of public shareholders from any transactions that harm investment interests. [7] There are two things that are emphasized in this concept. First, the importance of the right of shareholders to obtain the information correctly (accurately) and timely. Second, the company's obligation to make disclosure (disclosure) accurately, timely, and transparently to all information on company performance, ownership and stakeholders.[8]

Submission of an annual report is one form of GCG implementations in the Capital Market sector, especially towards the principle of openness. In article 4 POJK No.29/POJK.04/2016 concerning Annual Reports of Issuers or Public Companies.[9] The company's annual report consists of several contents, one of which is the audited annual financial report. So that the submission of accurate and transparent annual financial statements is a very important thing in protecting the legal rights of stakeholders.

However, in practice, there are still violations of the principles of GCG itself, especially in the submission of annual financial statements. One example in the 2018 financial statements of SOE companies, namely PT. Garuda Indonesia (Persero). This case also led to the imposition of administrative sanctions by the Financial Services Authority (OJK) and the Indonesia Stock Exchange (BEI) against PT. Garuda Indonesia (Persero) .Tb because it was considered to violate the provisions of existing accounting standards and as an issuer violated the provisions in Capital Market law.

Based on the description, the formulation of the problems that can be arranged are:

1. What are violations of the principles of Good Corporate Governance (GCG) in the delivery of the 2018 financial statements by PT. Garuda Indonesia (Persero) Tbk?

2. How is the mechanism for giving sanctions for violations of the principles of Good Corporate Governance (GCG) in the submission of the 2018 financial statements by PT. Garuda Indonesia (Persero) Tbk?

\section{Method}

\subsection{Approach Method}

The approach method used in this study is a normative juridical approach. The specifications used in this study are analytical descriptive. Analytical descriptive by giving an overview.[10] So this research is expected to be able to analyze the violation of GCG principles by describing the principles of GCG itself.

\section{Results}

\subsection{Case Position:}

- April 1, 2019, as a public company, PT. Garuda Indonesia (Persero). Tbk reported the financial performance of the 2018 to the OJK. On its financial statements, the company managed to get a net profit of US \$ 809 thousand, where in 2017 the company lost US \$ 216.58 million. 
- April 24, 2019, PT. Garuda Indonesia (Persero) .Tbk held an Annual General Meeting of Shareholders (AGM), where one of the agenda was to approve the company's consolidated financial statements for the 2018 fiscal year which had been audited by KAP Tanubrata Sutanto Fahmi Bambang \& Partners (BDO) on February 28, 2019. In the meeting, two Commissioners of PT. Garuda Indonesia (Persero) Tbk, Chairal Tanjung and Dony Oskaria meant to submit it through an objection letter at the AGM. Chairal Tanjung asked that the objection to be read out at the AGM, but upon the decision of the chair of the meeting the request was not granted. The results of the meeting finally approved the financial statements of PT. Garuda Indonesia (Persero) .Tbk 2018. As for the reasons for the objections of the two Commissioners to sign the financial statements, they were not included in the company's annual report.

- April 25, 2019, the market responded to the chaotic financial statements of PT. Garuda Indonesia (Persero). Tbk, a day after the news of the rejection of financial statements by two Commissioners was circulating. BEI said it would call the management of PT. Garuda Indonesia (Persero). Tbk and public accounting firm (KAP) Tanubrata Sutanto Fahmi Bambang and Partners as auditors of the company's financial statements related to the emergence of differences of opinion between the Commissioners and management of the financial statements for the 2018 fiscal year.

- April 26, 2019, Commission VI of the House of Representatives (DPR) said it would discuss the case in an internal meeting after the recess.

- 30 April 2019, IDX met the management of PT. Garuda Indonesia (Persero) .Tbk and public accounting firm (KAP) Tanubrata Sutanto Fahmi Bambang \& Partners. While, the Minister of Finance claimed to have asked the Secretary General of the Ministry of Finance Hadiyanto to study the chaos related to the SOE's financial statements.

- May 2, 2019, OJK asked IDX to verify the truth or difference of opinion regarding revenue recognition in the financial statements of PT. Garuda Indonesia (Persero) .Tbk in 2018.

- $\quad$ May 3, 2019, PT. Garuda Indonesia (Persero). Tbk finally issued an official statement after its financial statements were rejected by two of its Commissioners.

- May 8, 2019, chaotic financial statements of PT. Garuda Indonesia (Persero). The bank also dragged the name of the company PT. Mahata Aero Technology. By signing a partnership with PT. Garuda Indonesia (Persero) .Tbk, PT. Mahata Aero Teknologi recorded a debt of USD239 million to PT. Garuda Indonesia (Persero). Tbk and by PT. Garuda Indonesia (Persero). Tbk was recorded in the Financial Statements as of December 31, 2018 in the income column.

- May 21, 2019, PT. Garuda Indonesia (Persero) Tbk was summoned by Commission VI of the House of Representatives of the Republic of Indonesia (DPR-RI) for questioning.

- June 14, 2019, the Ministry of Finance (Ministry of Finance) has completed an examination of KAP Tanubrata Sutanto Fahmi Bambang \& Partners and concluded that there are allegations of audits that are not in accordance with accounting standards.

- June 18, 2019, IDX is still waiting for the final decision from the FSA related to sanctions that will be given to PT. Garuda Indonesia (Persero). Tbk. The stock management at that time had coordinated intensively with the OJK.

- June 28, 2019, through a press release, the IDX, OJK and the Ministry of Finance dropped sanctions to PT. Garuda Indonesia (Persero). Tbk and KAP Tanubrata Sutanto Fahmi Bambang \& Partners, auditors of the financial statements of PT Garuda Indonesia (Persero) Tbk and Subsidiaries for Fiscal Year 2018. 


\section{Discussion}

\subsection{Forms of Violations of Good Corporate Governance (GCG) Principles in the submission of the 2018 financial statements by PT. Garuda Indonesia (Persero). Tbk}

\subsubsection{Application of Good Corporate Governance (GCG) Principles for Companies PT. Garuda Indonesia (Persero). Tbk}

PT. Garuda Indonesia (Persero). TB is a state-owned company and also an issuer that applies GCG principles. GCG implementation for PT. Garuda Indonesia (Persero). Tbk is a necessity as mandated in SOE Ministerial Regulation No. PER-01/MBU/2011 concerning the Implementation of Good Corporate Governance (GCG) in SOEs which was later refined in SOE Ministerial Regulation No. PER-09/MBU2012 and Financial Services Authority Regulation (POJK) Number 21/POJK.04/2015 concerning Implementation of Guidelines for Public Company Governance. PT. Garuda Indonesia (Persero). TB has a full commitment to always apply the principles of Good Corporate Governance (GCG) in its business activities. This commitment is carried out by trying to continue to make improvements in the implementation of GCG, so that the Company will always be trusted by the stakeholders (stakeholders) to grow sustainably (sustainable growth) and gain profits (profit). Believes that the implementation of governance a good company will support the achievement of company goals and provide added value for shareholders.

\subsubsection{Violation of Good Corporate Governance Principles (GCG) Transparency}

This principle recognizes that shareholders and other stakeholders have the right to obtain true, accurate, and transparent information regarding company material information or facts. In addition, the obligation to implement the principle of transparency for companies has been mandated in the Company Law, namely:

1. Obligations of the Board of Directors regarding the disclosure of company information in the form of annual reports and can be examined by shareholders and non-compliance will result in sanctions; (Article 66 paragraph (1) and (2), Article 67 paragraph (1), 69 paragraph (3), and 100 paragraph (1) letter b of Company Law);

2. Obligation for Directors to ask public accountants to audit financial statements for companies that meet certain criteria (Article Article 68 paragraph (1) of PT Law), and

3. The right of shareholders to obtain information relating to the company from the Directors and/or Board of Commissioners, as long as it is related to the agenda of the GMS and is in line with the interests of the company (Article 75 paragraph (2) of the PT Law).

In the case of its violations, it was proven that PT. Garuda Indonesia (Persero). Tbk has been negligent in ratifying the consolidated financial statements for the 2018 financial year which has been audited by KAP Tanubrata Sutanto Fahmi Bambang \& Partners. This is related to the cooperation agreement between PT. Garuda Indonesia (Persero). Tbk with PT. Mahata Aero Technology regarding installation of connectivity and entertainment services. Furthermore, the author tries to explain it by outlining the consolidated financial statements for the 2018 of PT. Garuda Indonesia (Persero). Tbk, as follows:

- In the profit and loss column, it can be seen that in 2017 , companies with the stock code "GIAA" suffered a loss of USD213,389,678, but then experienced a profit in 2018 amounting to USD5,018,308. 
- From the explanation of number 42 , that is, on other parts of other revenues, it is known that the main contributor to other miscellaneous income came from compensation of the right to install in-flight connectivity and entertainment service equipment and content management.

- In the other receivables column in the company's financial statements, it can be seen that the assignment of rights recorded as USD239,940,000. In fact, amounted to USD233,134,000, - still in the form of receivables, not yet paid by PT. Mahata Aero Technology.

Provisions regarding leases are regulated in the Statement of Financial Accounting Standards (PSAK) 30. If a transaction between PT. Garuda Indonesia (Persero). Tbk with PT. Mahata Aero Teknologi is a rental transaction. In such case, according to PSAK 30 concerning rent, income recognized by PT. Garuda Indonesia (Persero). Tbk as the lessor is recorded using the straight-line method during the lease period, except if the use of the benefits on the assets decreases. But according to the explanation of number 42 in the financial statements, it was stated that PT. Mahata Aero Teknologi will bear the entire cost of providing, implementing, installing, operating, maintaining and dismantling and maintaining, including in the event of damage, replacing and/or repairing connectivity service equipment in flight and in-flight entertainment and content management. So according to the explanation of number 42 the provision, implementation, installation, operation, maintenance and dismantling is carried out by PT. Mahata Aero Technology.

In addition, in the determination related to the ratification of the company's annual financial statements through the AGM, the chair of the meeting did not read the reasons for the objections submitted by the two Commissioners namely Chairal Tanjung and Dony Oskaria and also did not contain the reasons for not signing the company's financial statements by the two Commissioners in the annual report. company-owned, so in the event that it is clear that the event has violated the principle of transparency (transparency) in GCG.

\section{Responsibility}

The principle of responsibility covers matters relating to the fulfillment of corporate social obligations as part of the community. The company in fulfilling its responsibilities to shareholders and other stakeholders must comply with applicable laws and regulations. In short, the company must uphold the rule of law.

In this case it is clear that as an issuer, PT. Garuda Indonesia (Persero). Tbk has violated the provisions of the applicable Capital Market law. This is proven by the sanctions issued by OJK to PT. Garuda Indonesia (Persero). Tbk through press release No. SP 25/DHMS/OJK/VI/2019 issued on 28 June 2019 are as follows:[11]

1) Violation of OJK Regulation Number 29/POJK.04/2016 concerning Annual Reports of Issuers or Public Companies. The reason: POJK already stated that if there are Directors/Commissioners not signing the financial statements, then it must be loaded in the annual report

2) Article 66 of the PM Law jis. OJK Regulation Number 13/POJK.03/2017, Audit Standards (SA) 315 Professional Standards of Public Accountants (SPAP) on Identification \& Assessment of Risk of Material Presentation Through Understanding of Entities and Environments, SA 500 SPAP on Audit Evidence, SA 560 SPAP concerning Subsequent events, and SA 700 SPAP regarding the Formulation of an Opinion and Report on Financial Statements. 
3) Violations of Article 69 of Law Number 8 of 1995 concerning Capital Market (UUPM) jis. Bapepam and LK Regulation Number VIII.G.7 concerning Presentation and Disclosure of Financial Statements of Issuers and Public Companies.

4) Violation of Bapepam Regulation Number VIII.G.11 concerning Directors' Responsibility for Financial Statements.

5) Violations of the provisions of Number III.1.2 IDX Regulation Number I-E concerning Obligation to Submit Information, which regulates Financial Statements, must be prepared and presented in accordance with Bapepam Regulation Number VIII.G.7. concerning Guidelines for Presentation of Financial Statements, and Guidelines for Presentation and Disclosure of Issuer's Financial Statements.

In addition to these rules, PT. Garuda Indonesia has violated the provisions of the legislation in the Company Law, such as:

1) The Board of Directors' obligations regarding the disclosure of company information in the form of annual reports and can be examined by shareholders and non-compliance will result in sanctions (Article 66 paragraphs (1) and (2), Article 67 paragraph (1), 69 paragraph (3), and 100 paragraph (1) letter b UUPT);

2) The right of shareholders to obtain information relating to the company from the Directors and/or Board of Commissioners, as long as it is related to the agenda of the GMS and is in line with the interests of the company (Article 75 paragraph (2) of the PT Law).

3) Fiduciary Duties for the Directors in carrying out the management of the company in good faith and full of responsibility with the consequences of personal liability for the company's losses if negligent (Article 92 paragraph (1) and Article 97 paragraph (1) - (3) UUPT); and

4) Fiduciary Duties for the Board of Commissioners in supervising company management policies in good faith with the consequences of personal liability for company losses if negligent (Article 108 paragraphs (1) and 114 paragraphs (1) - (2) UUPT).

\section{Accountability}

The Accountability Principle states that a company's management framework must ensure the company's strategic guidelines, effective supervision of the management of the accountability board to the company and its shareholders. This principle has implications for the legal obligations of the Directors, which are required to establish a relationship based on trust with shareholders and the company. Directors must not have a personal interest in making decisions and acting actively, both and based on information obtained thoroughly.[12]

In this case, it can be seen that there were an ineffective internal controls in the management of the company both between the Directors and Commissioners and to the Audit Committee as an Additional Organ of the company. This is evidenced by the decision-making mechanism in ratifying the consolidated financial statements for the 2018 financial year which was then signed by the Directors having ignored the objections raised by the two Commissioners of PT. Garuda Indonesia (Persero) .Tb, namely Chairal Tanjung and Dony Oskaria because they were deemed not in accordance with the existing accounting standards, because the chairman of the AGM refused to read out objections raised by the two Commissioners of the company, the company also did not include the reasons of the two Commissioners for not sign the company's annual financial report in the company's annual report. 
In addition, there was a negligence of the company in the selection of external auditors to audit the annual financial statements of PT. Garuda Indonesia (Persero) .Tb and there was an inaccuracy of the company in accepting and ratifying the 2018 financial statements that have been audited by KAP Tanubrata Sutanto Fahmi Bambang and Partners, where the company should be able to maximize the function of the Audit Committee as the internal audit controller of the company's financial statements in ensuring the security of the information presented in the company's financial statements, so that this results in harming the legal rights of stakeholders. In this case, it can be concluded that PT. Garuda Indonesia (Persero). TB has violated the principle of accountability in GCG.

\subsection{Mechanisms for Imposing Sanctions Against Violations of Good Corporate Governance (GCG) Principles in Submitting the 2018 Financial Statements by PT. Garuda Indonesia (Persero). Tbk}

\subsubsection{Authority of Granting Sanctions}

The violation of GCG principles in the submission of the 2018 financial statements by PT. Garuda Indonesia (Persero). Tbk is a form of violation in the Capital Market sector. In this case, the capital market sector is part of the financial services sector. Therefore, the institution that has the authority to implement a system of regulation and supervision that is integrated with all activities in the financial services sector is the OJK, as mandated in article 5 of Law No. 21 of 2011 concerning OJK (OJK Law).[13]

In this case, in exercising its authority, OJK coordinates with other institutions namely the IDX and the Ministry of Finance in the field of the Financial Professional Development Center (PPPK). This is done in an effort to support the effectiveness of the implementation of tasks by the OJK. In the context of law enforcement, OJK's authority is to:

a) Conduct audits in the Capital Market sector;

b) Investigate in the Capital Market;

c) Authorize the administration

d) Authorize the civil field.

\subsubsection{Sanction mechanism:}

\section{Inspection}

OJK has the authority to conduct audits in the Capital Market sector. The examination was conducted when there were alleged violations of the laws and regulations in the Capital Market sector. Investigation of alleged violations can come from internal sources (including the results of supervision and monitoring) or external sources (including SRO reports or complaints from the public). Based on the results of the examination,, the FSA can take action to foster or impose administrative sanctions for violations of statutory provisions in the Capital Market sector. If the results of the examination are either found to indicate an violation of the Capital Market criminal provisions or loose the interests of the Capital market, the results of the examination can be upgraded to the investigation stage. However, if the violation does not constitute a criminal offense, the results of the examination are recommended to the OJK Capital Market Supervisory Executive Chief along with proposed administrative actions in the form of administrative sanctions and/or Written Orders as stipulated in POJK No.36/POJK.04/2018 concerning Procedures for Examination in the Capital Market Sector.[14] 


\section{Determination of Administrative Actions}

Based on the formulation of article 14 paragraph (3) POJK No.36/POJK.04/2018 concerning Procedures for Examination in the Capital Market Sector, the authority to impose administrative sanctions is the Chief Executive of the OJK Capital Market Supervisor, whose decision-making is based on the recommendations of the examiner. In this case administrative sanctions given to PT. Garuda Indonesia (Persero). Tbk is in the form of fines and written warnings to improve and present the Annual Financial Statements of PT. Garuda Indonesia (Persero) Tbk as of December 31, 2018 and conducted a public expose of the improvement of the financial statements.

Related to administrative sanctions in the form of fines, the amount of fines that can be determined by the OJK in the Capital Market field has been explained in Government Regulation No.45 of 1995 concerning Conducting Activities in the Capital Market Sector as amended by Government Regulation of the Republic of Indonesia No. 12 of 2004 concerning Amendments to Government Regulation No. 45 of 1995 concerning Organizing activities in the Capital Market.[15]

\section{Conclusion}

1. In the case of violation of GCG principles committed by PT. Garuda Indonesia (Persero). Tbk in the submission of the company's 2018 financial statements consists of:

a) Transparency

b) Responsibility

c) Accountability)

2. In the of sanction mechanism carried out by the OJK in coordinating with the IDX and the Ministry of Finance has been in accordance with applicable laws and regulations. The mechanism is as follows:

a) Through examination. The legal basis for the audit by OJK is written on POJK No.36/POJK.04/2018 concerning Procedures for Examination in the Capital Market Sector. The procedure for the inspection will commence after obtaining the appointment of the OJK Capital Market Supervisory Executive Chief. After the inspection, the examiner makes a report on the results of the inspection to be used as a basis to prove the presence or absence of violations of the provisions of the legislation in the capital market sector to the OJK Capital Market Supervisory Executive Chief.

b) The imposition of administrative sanctions.. This is done by the OJK Capital Market Supervisory Chief Executive based on the recommendations of the examiner. In this case, administrative sanctions imposed on PT. Garuda Indonesia (Persero). Tbk for GCG violations is in the form of fines and written warnings to improve and restate PT Garuda Indonesia (Persero) Tbk Annual Financial Statements as of December 31, 2018, and conduct public exposures for the improvement of the financial statements. 


\section{References}

[1] M. Faudy, Perlindungan Pemegang Saham Minoritas. Bandung: CV Utomo, 2005.

[2] Law No. 40 of 2007 concerning Limited Liability Companies (UUPT). .

[3] Bank Indonesia Regulation No. 8/4PBI/2006 concerning GCG Implementation for Commercial Banks and for State-Owned Enterprises (BUMN). .

[4] "BUMN Minister Regulation No. PER-01/MBU/2011 concerning the Implementation of Good Corporate Governance (GCG) in SOEs."

[5] "BUMN Minister Regulation No. PER-09/MBU2012 regarding changes to the above."

[6] K. N. K. Governance, Pedoman umum good corporate governance Indonesia. Jakarta: Komite Nasional Kebijakan Governance, 2006.

[7] Law No. 8 of 1995 concerning Capital Markets. .

[8] R. Khairandy and C. Malik, Good Corporate Governance: Perkembangan Pemikiran dan Implementasinya di Indonesia. Yogyakarta: Kreasi Total Media, 2007.

[9] Financial Services Authority Regulation Number 21/POJK.04/2015 concerning Application of Guidelines for Public Company Governance. .

[10] J. Supranto, Metode penelitian hukum dan statistik. Jakarta: Rineka Cipta, 2003.

[11] Otoritas Jasa Keuangan (OJK), “Siaran Pers Otoritas Jasa Keuangan Berikan Sanksi Kasus Pt Garuda Indonesia (Persero) Tbk, (SP 25/DHMS/OJK/VI/2019),” Jakarta, 2019.

[12] Hasnati, Peranan Komie Audit dalam Organ Perseroan Terbatas dalam Kerangka Good Corporate Governance. Yogyakarta: FH UII Press, 2004.

[13] Law No. 21 of 2011 concerning the Financial Services Authority. .

[14] OJK Regulation No. 36/POJK.04/2018 concerning Procedures for Investigation in the Capital Market Sector. .

[15] Government Regulation of the Republic of Indonesia No. 12 of 2004 concerning Amendments to Government Regulation No. 45 of 1995 concerning Organizing activities in the Capital Market. . 